\title{
Variability of suspended sediment grain size distribution in winter floods
}

\author{
AGNIESZKA HEJDUK ${ }^{1}$, LESZEK HEJDUK ${ }^{2}$ \\ ${ }^{1}$ Laboratory - Water Center, ${ }^{2}$ Department of Water Engineering \\ Warsaw University of Life Sciences - SGGW
}

\begin{abstract}
Variability of suspended sediment grain size distribution in winter floods. The work presents the results of research concern variability of suspended sediment grain size, transported during the winter floods in agricultural catchment, in the period of hydrological years 2012-2015. The information about grain size distribution from nine winter flood events were collected over the study period, which allowed to analyze the variability of suspended sediment particle size during the various events. Grain size of sediment was determined using a laser particle size analyzer Mastersizer Microplus from Malvern Instruments Ltd. Variability of individual particle size classes were observed in each flood. Sand fraction dominated in seven of nine measured events. There was no significant increase of suspended sediment size in relation to the maximum of discharge. It can be explain by a relatively low discharge of recorded events. The percentage of material classified as clay $(<4 \mu \mathrm{m})$ ranged from 0.08 to $1.01 \%$, silt-sized material $(>4$ and $<63 \mu \mathrm{m}$ ) ranged between 9.31 and $67.17 \%$ and sand-size material $(>63 \mu \mathrm{m})$ ranged from 32.01 to $90.61 \%$. The relationship between the particle size and the discharge requires further studies. The diameter $d_{10}, d_{50}$ and $d_{90}$ and a standard deviation were calculated for each flood. Mean values of $d_{50}$ for individual flood ranged between 41.05 and $191.32 \mu \mathrm{m}$ with average value of $99.01 \mu \mathrm{m}$ and average standard deviation of 32.57 .
\end{abstract}

Key words: winter floods, suspended sediment grain size, characteristic diameters, laser particle size analyzer Mastersizer Microplus

\section{INTRODUCTION}

Erodibility of rains and surface runoff is lower in Poland in the winter time, than in the summer (Banasik and Górski 1994, Banasik et al. 1995), however less intensive vegetation cover or total lack of plants may increase the erosion in winter. Vegetation protects the soil particles against detachment and splashing, reducing erosion losses. Mazur (2005) noted based on five years of field observation in Bystrzanka catchment, that erosion damage caused by meltwater runoff were higher than the one caused by rainfall, especially in the fields sown with cereals (both winter crops and spring cereals). The erosion processes are the main driving force which cause sediment transport within catchments and into recipient. The increase of erosion processes during as well as snowmelt and rainfall events, cause increasing of sediment transport in rives. Modeling of the erosion processes and sediment transport in river can be describe by the for example DR-USLE equation (Banasiak et al. 2012). One of the six factors considered in this equation is a $K$ - erodibility factor 
which contains the sizes of eroded particles. Those particles when reach the river become partially an suspended sediment. Chanel response to sediment supply depends inter alia on flood magnitude (Ferreira et al. 2015). The mode of sediment transport to a certain extent is depended on the particle size, which is mentioned as one of the most important parameters of sediment transport (Dey 2014). The winter condition, when the vegetation land cover have less protective impact (Bogen 1992), could have stronger influence on particle size distribution during snowmelt floods.

The comparison of long-term investigation of grain size distribution performed by time integrated sampler (Banasik and Hejduk 2005) indicates that during winter-spring periods the grains sizes were smaller in comparison to summer-autumn periods. This observations were explained by the differences between average flows in both periods. However, those investigation do not focused on floods itself. The first attempt of recognition of grain size distribution during floods in Zagożdżonka River were performed based on six events rainfall or snowmelt events (Hejduk et. al 2006). The research shows strong variation of grain sizes during a flood propagation and the highest variation can be seen in values of $d_{90}$, what can suggest that the biggest particles varied the most during the flood.

Those evidences indicated to a more precise recognition of suspended sediment grain size distribution behavior within floods events during snowmelt periods. In this paper the results of three-year investigation of grain size distri- bution for winter events are presented. The main purpose of this research was a recognition of grain sizes patterns during snowmelt floods in a small agricultural catchment with mainly sandy soils and the relation between characteristic diameter as well as sediment classis types.

\section{STUDY CATCHMENT}

\section{Location, topography and area}

The investigation was based on the data collected by the Department of Hydraulic Engineering of Warsaw University of Life Sciences-SGGW from the $23.4 \mathrm{~km}^{2}$ lowland watershed of Zagożdżonka river at the Czarna gauging station. Located in central Poland (Fig. 1) Zagożdżonka river is a left tributary of Vistula river. The catchment area, which contributes to direct runoff and sediment delivery (without local depressions) to river system, is $19.6 \mathrm{~km}^{2}$, upstream of Czarna gauge. Absolute relief is $26.5 \mathrm{~m}$ in the upper subcatchment (shown as B in Fig. 1), and $34 \mathrm{~m}$ in the entire watershed (A - Fig. 1). The mean slopes of main streams are from 2.5 to $3.5 \mathrm{~m}$ per $1,000 \mathrm{~m}$ (Hejduk L. and Banasik 2010).

\section{Soils and land use}

Sandy soils (from almost pure to loamy sands), which covered $90 \%$ of watershed to Czarna gauging station are the main type of soils. In local depressions and river flood plains peaty soils may be found. Land use in the watershed upstream of Czarna is dominated by arable land $-70 \%$ of total area; $20 \%$ of area is 


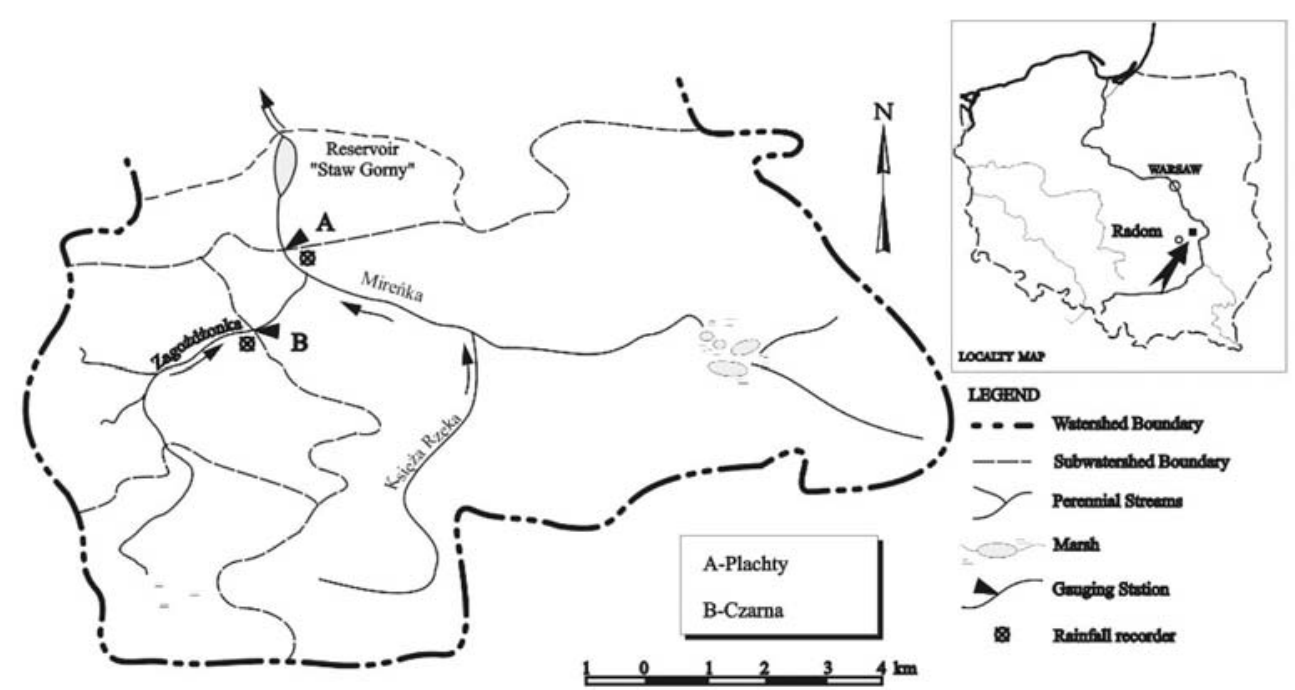

FIGURE 1. Locality map of the watershed

covered by forest, $9.4 \%$ is pastures and $0.6 \%$ is paved areas.

\section{Precipitation and runoff}

According to Banasik et al. (2013) the mean annual precipitation and runoff for Zagożdżonka catchment from the period of time 1963-2011 are estimated at $612 \mathrm{~mm}$ (range from $941 \mathrm{~mm}$ in 1974 to $414 \mathrm{~mm}$ in 1991) and $107 \mathrm{~mm}$ respectively (range from $209 \mathrm{~mm}$ in 1980 to $52 \mathrm{~mm}$ in 1992). The month with the highest rainfall (average $81.8 \mathrm{~mm}$ ) is July, while the precipitation in January is the lowest in the year $(31.7 \mathrm{~mm})$. The month which is the most abundant in water is March, while the most dry is July (Banasik et al. 2013). The snow cover usually appears between 25 and 30 of November and disappears between 20 and 25 of March, with the total number of days with snow cover equal to 70 (Chrzanowski 1988). The snowmelt period is usually 1-4 days long (Hejduk and Hejduk 2014).

\section{Winter floods}

According to Kaznowska et al. (2015), most days with flood flows in Zagożdżonka catchment between 1963-2012 were noted in February, March and April, while droughts occur mostly in summer, half of the hydrological year. Most of the floods are short, but the longest one were noted in winter time. The average discharge of the years 1991-2012 for Zagożdżonka river at Czarna gauging station is $0.074 \mathrm{~m}^{3} \cdot \mathrm{s}^{-1}(\mathrm{Ka}-$ znowska et al. 2015). Two-year flood discharge $\left(W Q_{50 \%}\right)$ has been estimated for $1.04 \mathrm{~m}^{3} \cdot \mathrm{s}^{-1}$ (Hejduk A. and Banasik 2010). The mean annual suspended sediment concentration (SSC) is low and has been estimated for $14 \mathrm{mg} \cdot \mathrm{l}^{-1}$ (Hejduk et al. 2006), however for snowmelt floods it has been estimated for $19.5 \mathrm{mg} \cdot \mathrm{l}^{-1}$ (Hejduk A. and Banasik 2010). Yearly total sediment yield from Czarna station is about $60 \mathrm{Mg}$ (Banasik 1983). Winter floods in Zagożdżonka River are in most cases snowmelt-rainfall or rainfall one. 
TABLE 1. General information of analyzed winter events recorded at Czarna gauge station

\begin{tabular}{|l|c|c|}
\hline Category & Average & Range \\
\hline Runoff coeficient, $\alpha(-)$ & 0.15 & $0.03-0.70$ \\
\hline Peak discharge, $Q_{\max }\left(\mathrm{m}^{3} \cdot \mathrm{s}^{-1}\right)$ & 0.462 & $0.115-2.034$ \\
\hline Average discharge, $Q_{a}\left(\mathrm{~m}^{3} \cdot \mathrm{s}^{-1}\right)$ & 0.292 & $0.089-1.360$ \\
\hline$Q_{\max } / W Q_{50 \%}{ }^{-1}$ & 0.444 & $0.111-1.956$ \\
\hline Total supply, $M P(\mathrm{~mm})$ & 15.79 & $6.40-55.50$ \\
\hline Effective supply, $M P_{e f}(\mathrm{~mm})$ & 1.67 & $0.25-5.11$ \\
\hline Event mean diameter of suspended sediment $d_{50}(\mu \mathrm{m})$ & 99.01 & $41.05-191.32$ \\
\hline Flood average suspended sediment concentration & 21.63 & $6.21-79.5$ \\
\hline Mass of transported sediment $(\mathrm{Mg})$ & 2.70 & $0.20-17.71$ \\
\hline
\end{tabular}

*Two-year flood discharge $W Q_{50 \%}=1.04 \mathrm{~m}^{3} \cdot \mathrm{s}^{-1}$.

They can provide the biggest amount of suspended sediment during hydrological year.

\section{MATERIAL AND METHODS}

\section{Water sampling}

Suspended sediment transport in small lowland rivers such as Zagożdżonka even during floods is not large compared to the mountain rivers or large lowland rivers. Relatively low suspended sediment concentration cost difficulties in the studies of grain size distributions.

Automatic refrigerated sampler AmericanSigma 800XL, installed at the Czarna station was used for point water sampling during snowmelt floods. The sampler is able to take maximum 24 samples with two-hour time step. The sample is taken after exceeding a certain water level, which is the limit above which water levels are considered to be flood for Czarna station: more than twice the mean annual discharge (Hejduk L. and Banasik 2010). In the case of 48hour-long floods, the maximum number of samples can be taken. During shorter events, the equipment automatically ceased to collect water samples, after the limit of water level was reached. Collected samples were then transported to the laboratory of Warsaw University of Life Sciences - SGGW where the grain size of transported suspended sediment and it's concentration were determined.

\section{Determination of suspended sediment grain size distribution}

Analysis of suspended sediment grain size were carried out using Low Angle Laser Light Scattering method (laser diffraction method), based on the phenomenon of light scattering (Rawle 1997). Suspended sediment grain size and its distribution ware determined using a laser particle size analyzer Mastersizer Microplus from Malvern Instruments Ltd. According to the specifications provided by the producer (Malvern Ltd. 1997), Mastersizer Microplus allows to measure the particle's diameter in the range of 0.05 $-550 \mu \mathrm{m}$, with an accuracy of $\pm 2 \%$ of the particle diameter. The main part of the equipment is the He-Ne laser with power of 2 MW. It gives a beam of laser light 
having a wave length of $633 \mathrm{~nm}$. Particle size measurement is made at $10 \mu \mathrm{s}$. The average value of a specified number of measurements is taken as a conclusive value. The number of measurements taken into account for the calculation of the average value depends on the user. The minimum recommended number of individual measurements should not be less than 2,000. In case of described research the final result was assumed as average value of 5,000 individual measurements. The measurement of suspended sediment grain size is carried out in a closed portion of the equipment.

The sample is repeatedly pumped through the measuring chamber, illuminated with laser light. The sample is continuously mixed for a stirrer with adjustable speed, prevents sedimentation of heavier particles (Fig. 2). In fact, the sample sucked into the sample chamber is homogeneous.

Software calculates and reports the result of measurement for example as the percentage of the particles having specific sizes. Sediment particles' shapes are irregular, and it is difficult to describe its size as one diameter. Laser diffraction method define the diameter of sphere equivalent to particle in terms of volume (nominal diameter). This means that the resulting value of the diameter is the diameter of a sphere, which have the same volume as the analyzed particle.

\section{RESULTS AND DISCUSSION}

\section{Variability of suspended sediment grain size during floods}

In the period of winter season of hydrological years 2012-2015, the information about grain size distribution from nine flood events were collected. Sampling during the flood allowed to analyze the variability of suspended sediment particle's size. Most of the observed events were relatively small, so the maximum number of automatically collected samples never reached 24 . The equipment stopped collect samples right after the water level dropped below the accepted threshold. In one case, because of the equipment's breakdown, samples were collected manually, at irregular time step.

The method used for determining the particle size of suspended sediment gives the ability to determine grain size distributions as well as calculate the characteristic diameters of sediment. Suspend-
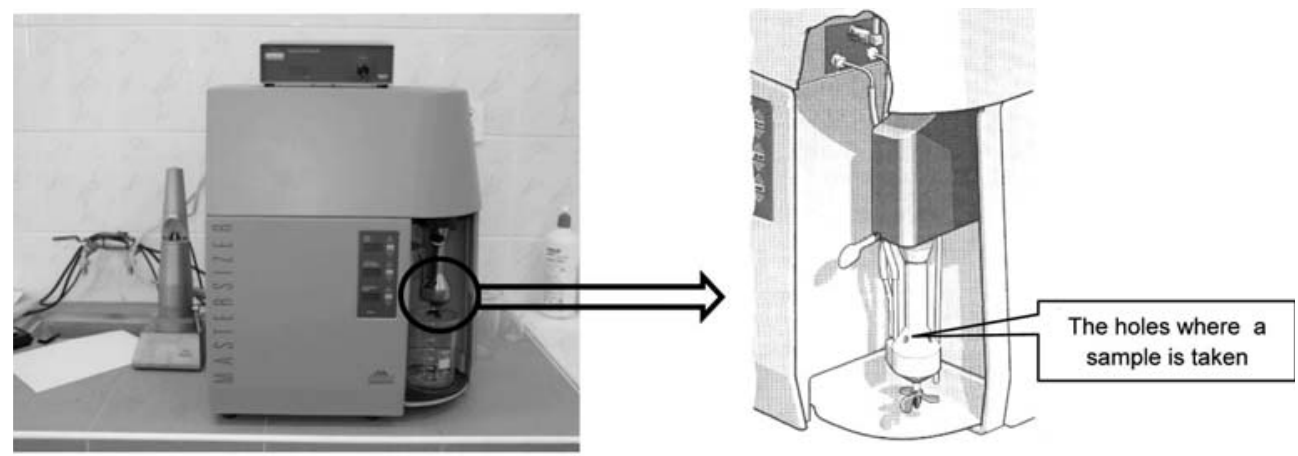

FIGURE 2. The view of Mastersizer Microplus (Malvern Ltd. 1997) 
ed sediment particles were classified by size using a scale proposed by Lan (Yang 1996, Morris and Fan 1998). According to Lan, classification grain size of $0.004 \mathrm{~mm}$ is the threshold between clay and silt; grain size equal to $0.062 \mathrm{~mm}$ is a threshold between silt and sand, and grain size equal to $2 \mathrm{~mm}$ is a threshold between sand and gravel. This classification allows to determine the variability of particles during each flood. Similar grade scale of sediment size is given by Dey (2014). The average results for each flood are given in Table 2. Dates specified in this table refer to the point, when the first sample was collected and they are different from the dates shown as the beginning of flood.

The number of automatically collected samples in particular flood ranged from 4 to 19. In one case samples were collected manually by an observer, at irregular time step (30 samples). Variability of individual particle size classes were observed in each flood. There was no significant increase of suspended sediment size in relation to the maximum of discharge. It can be explained by low values of observed flow in general. The percentage of material classified as clay $(<4 \mu \mathrm{m})$ ranged from 0.08 to $1.01 \%$, silt-sized material ( $>4$ and $<63 \mu \mathrm{m}$ ) ranged between 9.31 and $67.17 \%$ and sand-size material $(>63 \mu \mathrm{m})$ ranged from $32.01 \%$ to $90.61 \%$. The dynamics of particular size classes during floods are shown in Figure 3. Sand fraction dominated in seven of nine measured events. In the other two, sand fraction was significantly lower than the other factions (clay and silt). The average variability of the fraction is shown on Figure 4.

The diameter $d_{10}, d_{50}$ and $d_{90}$ were calculated for each flood. The values given in Table 3 represent the average of all samples in each flood. Standard deviation $(S D)$ describes the variability of individual characteristic diameters during a specific flood. The diameter $d_{10}$ ranged from 11.99 to $47.02 \mu \mathrm{m}$, with the average standard deviation 7.39. The low value of the deviation in the case of diameter $d_{10}$ suggests a slight variation of tiny particles during floods.

TABLE 2. The mean percentages of suspended sediment corresponding to the various classes of size in recorded floods

\begin{tabular}{|l|c|c|c|c|}
\hline \multirow{2}{*}{ Date } & \multirow{2}{*}{ Number of collected samples } & \multicolumn{3}{|c|}{ Class of size } \\
\cline { 3 - 5 } & & clay (\%) & silt (\%) & sand (\%) \\
\hline $05.11 .2012-06.11 .2012$ & 8 & 0.23 & 31.39 & 68.38 \\
\hline 20.01 .2012 & 5 & 0.28 & 17.23 & 82.49 \\
\hline $22.01 .2012-23.01 .2012$ & 12 & 0.35 & 16.91 & 82.74 \\
\hline $30.01 .2013-02.02 .2013$ & 10 & 0.46 & 44.19 & 55.35 \\
\hline 08.03 .2013 & 7 & 1.01 & 60.27 & 38.71 \\
\hline $10.03 .2013-11.03 .2013$ & 16 & 0.82 & 67.17 & 32.01 \\
\hline $07.04 .2013-12.04 .2013$ & $30^{*}$ & 0.34 & 39.71 & 59.95 \\
\hline 08.11 .2014 & 4 & 0.08 & 9.31 & 90.61 \\
\hline $22.12 .2014-24.12 .2014$ & 19 & 0.33 & 44.53 & 55.14 \\
\hline \multicolumn{3}{|c|}{} & \multicolumn{3}{|c}{ Average values } \\
\cline { 3 - 5 } & $\times$ & 0.43 & 36.75 & 62.82 \\
\hline
\end{tabular}

*Samples collected manually at irregular time step. 

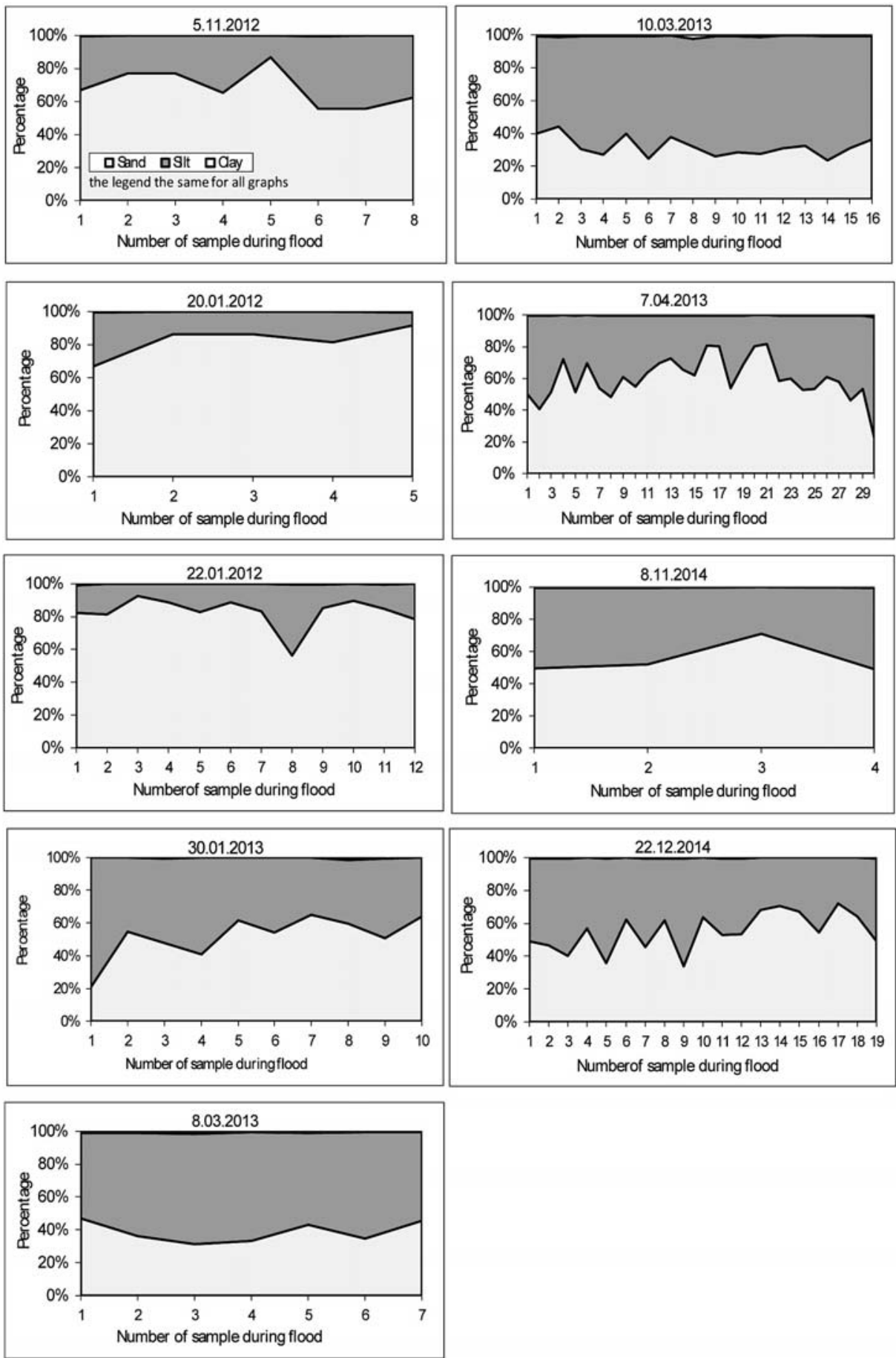

FIGURE 3. The dynamics of classes variation during the winter floods 


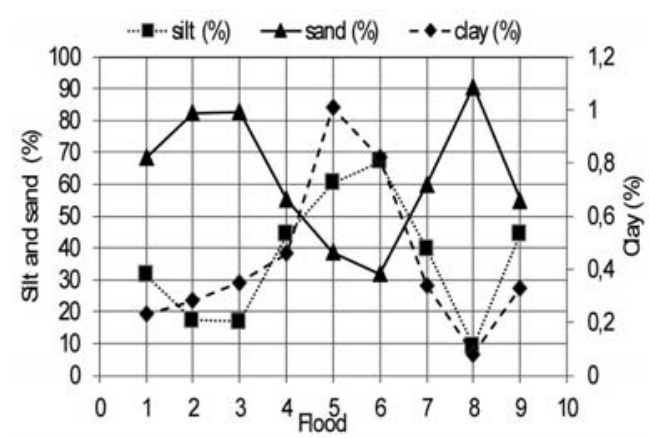

FIGURE 4. The average variability of the fraction

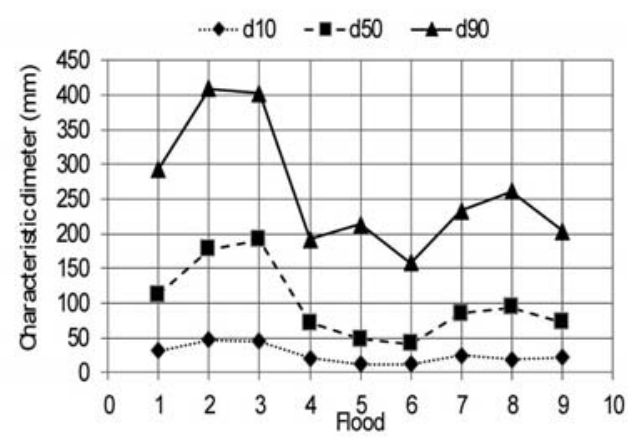

FIGURE 5. The average variability of characteristic diameters

TABLE 3. The average values (AVG) of the characteristic diameters $d_{10}, d_{50}, d_{90}(\mu \mathrm{m})$ during the respective floods, and the standard deviation $(S D)$

\begin{tabular}{|l|c|c|c|c|c|c|}
\hline \multirow{2}{*}{ Date } & \multicolumn{2}{|c|}{$d_{10}$} & \multicolumn{2}{c|}{$d_{50}$} & \multicolumn{2}{c|}{$d_{90}$} \\
\cline { 2 - 7 } & AVG & $S D$ & AVG & $S D$ & AVG & $S D$ \\
\hline $05.11 .2012-06.11 .2012$ & 31.47 & 9.06 & 111.78 & 54.95 & 293.13 & 71.03 \\
\hline 20.01 .2012 & 47.02 & 14.54 & 177.63 & 35.70 & 408.87 & 52.11 \\
\hline $22.01 .2012-23.01 .2012$ & 45.42 & 14.72 & 191.32 & 53.14 & 402.52 & 53.29 \\
\hline $30.01 .2013-02.02 .2013$ & 20.76 & 5.68 & 71.61 & 13.89 & 192.33 & 40.08 \\
\hline 08.03 .2013 & 11.99 & 1.68 & 47.51 & 7.11 & 213.08 & 88.87 \\
\hline $10.03 .2013-11.03 .2013$ & 12.09 & 1.95 & 41.05 & 5.69 & 157.85 & 62.59 \\
\hline $07.04 .2013-12.04 .2013$ & 24.68 & 7.74 & 84.66 & 32.02 & 233.22 & 81.72 \\
\hline 8.11 .2014 & 19.22 & 5.18 & 93.48 & 71.70 & 261.06 & 149.69 \\
\hline $22.12 .2014-24.12 .2014$ & 21.55 & 5.98 & 72.05 & 18.67 & 203.55 & 46.59 \\
\hline & \multicolumn{7}{|c|}{ Average values } \\
\cline { 2 - 7 } & 26.02 & 7.39 & 99.01 & 32.54 & 262.85 & 71.77 \\
\hline
\end{tabular}

The greatest variation deviations occurred in case of the diameter $d_{90}$. The value of the diameter $d_{90}$ ranged from 157.85 to $408.87 \mu \mathrm{m}$, with the average standard deviation 71.77. This suggests a high variability of the amount of the biggest particles during floods.

Mean values of $d_{50}$ for individual flood ranged between 41.05 and $191.32 \mu \mathrm{m}$ with average value of $99.01 \mu \mathrm{m}$ and average standard deviation 32.57. The av- erage value of $d_{50}$ for snowmelt floods recorded between 2004-2009 at Czarna gauging station were 71.61, with standard deviation 19.42 (Hejduk 2009). According to the previous research in this same catchment, the average value of $d_{50}$ for 2012-2015 is closer to the value reported by Banasik and Hejduk (2005) for summer-autumn period of time. The reason for this might be meteorological conditions in the catchment. Based 
on thermal and snowiness classification (Hejduk and Hejduk 2014) in the analyzed period of time, winters in general were mild and less snowy, sometimes preceded by dry summers and autumns. The reaction of the catchment on winter supply was smaller than in previous years, as same as maximum discharge of the recorded floods. Although there was no significant relation between particle size and the discharge, there is a trend of increase of transport of larger particles within decreasing discharge. Bogen (1992) reported that the fine sediment is carried in transport with the increasing discharge.

The individual characteristic diameters (Fig. 5) did not show high variability between floods, but in the case of January 2012 floods ( 20 and 22 of January 2012), diameters $d_{50}$ and $d_{90}$ were much greater than the corresponding diameters in other flood events. Both these floods followed one another and were the first one after a very long dry autumn, which may explain why the grain size distribution curves were moved towards larger particles.

\section{CONCLUSIONS}

The results of investigations on suspended sediment grain size distributions during floods recorded in winter period of hydrological years in Zagożdżonka river show high variability of characteristic diameters and fractions. The characteristic diameter $d_{50}$, which is an indicator of average grains size, varied from 41.05 till $191.2 \mu \mathrm{m}$, depend on flood. Calculated standard deviation of particular characteristic dimeters during flood shows, that the highest variability was recorded for diameter $d_{90}$ and the lowest for dimeter $d_{10}$. That suggests relatively stable transport of small particles in a sense of size during floods. According to the Lane scale, which can be used for determination of sediment fraction based on grains sizes, the dominant fraction during seven out of nine investigated floods was sand. In two cases silt was the dominant fraction. Based on the results, there was no significant relation between sediment size and peak flow during particular flood. In case of two floods, the characteristic diameters $d_{50}$ and $d_{90}$ were significantly different from other floods. The reason for that might be a long, dry autumn, after which the floods occurred.

\section{Acknowledgments}

The investigation was carried on within the research project NN 305144540 funded by National Science Center. The support provided by the organization is gratefully acknowledged.

\section{REFERENCES}

BANASIK K. 1983: Rozmieszczenie użytków w zlewni jako czynnik minimalizujący natężenie transportu rumowiska $\mathrm{w}$ korycie rzecznym [Land use redistribution as factor minimalizing the sediment transport in river channel]. $\mathrm{PhD}$ thesis. Warsaw University of Life Sciences - SGGW. MS.

BANASIK K., HEJDUK L., HEJDUK A., KAZNOWSKA E., BANASIK J., BYCZKOWSKI A. 2013. Wieloletnia zmienność odpływu z małej zlewni rzecznej w regionie Puszczy Kozie-nickiej [Long-term variability of runoff from a small catchment in the region of the Kozienice Forest]. Sylwan 157 (8), 578 -586 . 
BANASIK K., GÓRSKI D. 1994: Rainfall erosivity for south-east Poland. In: Conserving soil resources: European perspectives. R.J. Rickson (Ed.). Selected papers from the First International Congress of the European Society for Soil Conservation, CABI International, 201-207.

BANASIK K., GÓRSKI D., POPEK Z., HEJDUK L. 2012: Estimating the annual sediment yield of a small agricultural catchment in central Poland. Erosion and Sediments Yields in the Changing Environment. Proceedings of symposium held at the institute Of Mountain Hazard and Environment, CAS-Chengdu, China, 11-15 October 2012. IAHS Publ. 356, 267-275.

BANASIK K., HEJDUK L. 2005: Badania granulometrii rumowiska unoszonego w małej rzece nizinnej [Grain size distribution of suspended sediment in small lowland river ]. Acta Agrophysica 5 (2), 253-262.

BANASIK K., SKIBIŃSKI J., GÓRSKI D. 1995: Metody oceny erozji powierzchniowej i akumulacji rumowiska $\mathrm{w}$ zbiornikach. [Evaluation methods of soil surface erosion and load accumulation in reservoir]. In: Metodyka zagospodarowania zasobów wodnych w małych zlewniach rzecznych [Methodology of management for water resources in small river catchment areas]. A. Ciepielowski (Ed.). Wydawnictwo SGGW, Warszawa, 63-78, 136-143.

BOGEN J. 1992: Monitoring grain size of suspended sediments in rivers. Erosion and Sediment Transport Monitoring Programs in River Basins. Proceedings of the Oslo Symposium, August 1992. IAHS Publ. 210, 183-190.

CHRZANOWSKI J. 1988: Pokrywa śnieżna w Polsce. Klasyfikacja jej grubości i regionalizacja [Snowcover in Poland. Classification of its thickness and regionalization]. Prace Badawcze IMGW. Meteorologia 43.
DEY S. 2014: Fluvial hydrodynamics. Hydrodynamic and sediment transport phenomena. Springer.

FERREIRA R., HASSAN M., FERRERBOIX C. 2015. Principles of bedload Transport of non-cohesive sediment in open channels. In: P. Rowiński, A. Radecki-Pawlik (Eds). Rivers-Physical, Fluvial, and Environmental Processes. GeoPlanet: Earth and Planetary Science. Springer International Publishing, 323-372. DOI: 10.1007/978-3-319-17719913.

HEJDUK A. 2009: Transport rumowiska unoszonego podczas wezbrań roztopowych w małej zlewni rolniczej [Suspended sediment transport during snowmelt floods events in small agricultural watershed]. $\mathrm{PhD}$ thesis. Warsaw University of Life Science - SGGW (Eng. summ.). MS.

HEJDUK A., BANASIK K. 2010: Suspended sediment concentration and yield in snowmelt flood events in a small lowland river. Annals of Warsaw University of Life Sciences - SGGW, Land Reclamation 42 (1), 61-68.

HEJDUK L., BANASIK K. 2010: Variation in suspended sediment grain sizes in flood events of a small lowland river. IAHS Publ. 337, 189-196.

HEJDUK A., HEJDUK L. 2014: Thermal and snow conditions of winters and winter floods on example of Zagożdżonka River. Annals of Warsaw University of Life Sciences - SGGW, Land Reclamation 46 (1), 3-15.

HEJDUK L., HEJDUK A., BANASIK K. 2006: Grain size distribution of suspended sediment during rainfall and snowmelt floods in small lowland river. EJPAU 9 (2), \#31.

KAZNOWSKA E., HEJDUK A., HEJDUK L. 2015: Charakterystyka występowania wezbrań i niżówek w małej zlewni Niziny Mazowieckiej [Characteristic of occurrence of floods and streamflow droughts in a small Mazovian Lowland catchment]. Woda - Środowisko - Obszary Wiejskie (8-9), 15, 3 (51), 45-59. 
RAWLE A. 1997: The basic principles of particle size analysis. Malvern Instruments Ltd.

MALVERN Ltd. 1997: Getting Started, MAN 0106. Malvern Intsruments Ltd. England.

MORRIS G.L., FAN J. 1998: Reservoir Sedimentation Handbook. McGraw-Hill, New York.

MAZUR A. 2005: Erozja gleb w rolniczej zlewni z okresowym odpływem wody na Wyżynie Lubelskiej w latach 1999-2003 [Soil erosion in agricultural basin with periodical water outflow in the Lublin Upland in 1999-2003]. Acta Agrophysica 5 (1), 85-92.

YANG T.C. 1996: Sediment Transport Theory and Practice. McGraw-Hill, New York.

Streszczenie: Zmienność uziarnienia rumowiska unoszonego podczas wezbrań zimowych. Praca dotyczy wyników badań zmienności uziarnienia rumowiska unoszonego, transportowanego podczas wezbrań zimowych w nizinnej zlewni rolniczej w latach hydrologicznych 2012-2015. W okresie badawczym zebrano informacje o rozkładach granulometrycznych $\mathrm{z}$ dziewięciu wezbrań, co pozwoliło na analizę zmienności wielkości cząstek rumowiska unoszonego podczas poszczególnych zdarzeń. Analizy granulometryczne rumowiska unoszonego przeprowadzono przy zastosowaniu laserowego analizatora wielkości ziaren firmy Malvern Instruments Ltd. o nazwie Mastersizer Microplus. Podczas wezbrań zaobserwowano zmienność poszczególnych klas wielkości cząstek rumo- wiska. W siedmiu przypadkach dominował materiał wielkością cząstek odpowiadający frakcji piasków. Nie stwierdzono znaczącego zwiększania się rozmiarów cząstek rumowiska w pobliżu przepływu kulminacyjnego, co może być tłumaczone niewielkimi wartościami przepływów analizowanych wezbrań. Procentowa zawartość materiału wielkości iłów $(<4 \mu \mathrm{m})$ zmieniała się od 0,08 do $1,01 \%$, materiału wielkości pyłów ( $>4$ and $<63 \mu \mathrm{m}$ ) od 9,31 do $67,17 \%$ i materiału wielkości piasków $(>63 \mu \mathrm{m}) \mathrm{w}$ zakresie od 32,01 do 90,61\%. Zależność między wielkością cząstek a przepływem wymaga dalszych badań. Dla każdego wezbrania określono wartości średnic charakterystycznych $d_{10}, d_{50}, d_{90}$. Wartości $d_{50}$ dla poszczególnych wezbrań zmieniały się od 41,05 do 191,32 $\mu \mathrm{m}$, przy wartości średniej $99,01 \mu \mathrm{m}$ i odchyleniu standardowym 32,57 .

\section{MS received February 2016}

\section{Authors' addresses:}

Agnieszka Hejduk

Laboratorium - Centrum Wodne

Wydział Budownictwa i Inżynierii Środowiska SGGW

ul. Nowoursynowska 166

02-787 Warszawa, Poland

e-mail: agnieszka_hejduk@sggw.pl

Leszek Hejduk

Katedra Inżynierii Wodnej

Wydział Budownictwa i Inżynierii Środowiska SGGW

ul. Nowoursynowska 166

02-787 Warszawa, Poland

e-mail: leszek_hejduk@sggw.pl 